\title{
THE INFLUENCE OF DIVIDEND POLICY, DEBT POLICY, INDEPENDENT COMMISSIONER, AND INSTITUTIONAL OWNERSHIP ON THE FIRM VALUE WITH GROWTH OPPORTUNITIES AS MODERATOR VARIABLES (Study on Non-Financial Companies Listed on IDX in the Period of Years of 2012-2015)
}

\author{
Lia Setiyawati ${ }^{1}$, Sugeng Wahyudi², Wisnu Mawardi ${ }^{3}$ \\ ${ }^{1}$ Master of Management, Faculty of Economics and Business, Diponegoro University \\ ${ }_{2}^{2}$ Master of Management, Faculty of Economics and Business, Diponegoro University \\ ${ }^{3}$ Master of Management, Faculty of Economics and Business, Diponegoro University
}

\begin{abstract}
Tobin's $q$ is the ratio of market value of equity plus the market value of debt to total assets. This ratio measures the value provided by financial markets for any management and organization as a growing company. Tobin's q also shows how far a company is able to create its value relative to the amount of capital invested. The greater the value of Tobin's q indicates that the company has good growth prospect. This study aimed at examining the influence of Dividend Payout Ratio (DER), Independent Commissioner (KI) and Institutional Ownership (INST) on Tobin's q with Size and Return on Investment (ROI) as control variable and Market to Book Value (MBV) as a moderating variable. The population in this study is all manufacturing companies listed on Indonesia Stock Exchange in the period of 2012-2015. The sampling technique used purposive sampling and obtained 28 companies becoming the research sample. The analysis technique used in this research was multiple regression analysis using SPSS where the data, previously, had been tested using classical assumption tests like normality, multicollinearity, and autocorrelation tests. The results of the model-1 research show that DPR, DER, KI, INST, SIZE, and ROI together influence Tobin's $q$ with adjusted $R 2$ of $94.5 \%$. While individually, DPR and SIZE relate negatively and insignificantly to Tobin's q. DER, KI, and ROI are related positively and significantly, while INST has a significant negative influence on Tobin's q. The model-2 research shows that DER, $D P R, K I, I N S T, S I Z E, R O I, M B V, D P R * M B V, D E R * M B V, K I * M B V$ and INST * MBV together effect on Tobin's $q$ with adjusted R2 of 92\%. While individually, DPR and ROI are related positively insignificant and SIZE is related negatively insignificant to Tobin's q. DER, KI, and MBV are positively significant, INST is significantly negative to Tobin's q. MBV moderates the influence of DPR, KI, and INST against Tobin's q. MBV does not moderate the effect of DER on Tobin's q.
\end{abstract}

Key Words : debt to equity ratio, dividend payout ratio, independent commissioner, institutional ownership, return on invesment, size, market to book value, Tobin's q.

${ }^{1}$ Corresponding author 


\section{INTRODUCTION}

The significant growth of Indonesian capital market is influenced by the performance of companies listed on the Indonesia Stock Exchange (IDX). Listed companies having stocks traded on the BEI that show good performance will increase the value of their companies in investors' viewpoints. In the world of capital markets, these macroeconomic indicators strongly affect the rise or fall of stock prices. The rise in inflation and interest rates is some of the factors causing the stock prices of some companies to tend to fall, because the increase in inflation rate will be a negative sentiment for stock investors.

A firm value can be affected by several factors such as dividend policy, debt policy, independent commissioner, and institutional ownership. A firm's dividend policy can be seen from its Dividend Payout Ratio (DPR). DPR shows the dividend ratio that the firm shares to its net income. The study by Myers (1977) viewed the value of a firm as the total asset value and growth prospects for making future investment decisions. Astudy conducted by Jensen (1986) suggested that problems in the growth opportunities of companies may arise due to lack of investment or too much investment in the company. The growth is expected to provide positive aspects for the company thus increasing the opportunity to invest in the company. For investors, the growth of the company is a profitable prospect, because investment is expected to provide high returns in the future. Growth opportunities are also referred to as investment opportunities. Investment opportunities are an option to invest in projects that have positive net present value.

This study aimed at expanding the researches on the value of companies that have been previously done by other researchers. There were only few researchers having examined the interaction between internal factors and growth opportunities with the firm value. Few performed studies had examined growth opportunities as a moderating effect with firm value. This study also included the size of the company and Return on Investment Ratio (ROI) as control variables, which aimed at reducing the influence caused by outside factors that are not careful in this study. The size of an already large company has easy access to capital markets. Contrarily, new and small companies will find it difficult. The larger the company's size the higher its value. Markets value the market value higher than the book value. Investors view that the larger the company, the more prospective its performance. Another control variable is ROI where an increase in corporate profits can attract investors to buy shares of the company so that it can increase its value.

\section{LITERATURE REVIEW \\ 1. Theory \\ Firm Value}

The main purpose of company, according to the theory of the firm, is to maximize the wealth or value of the firm (Salvatore, 2005). Maximizing the firm value is very important for a company, because maximizing the firm value means to maximize shareholder wealth that is the main goal of the company (Euis and Taswan, 2002). Corporate value is often proxied by using Tobin's q. Tobin's $\mathrm{q}$ is the ratio or theory which in 1969 was first introduced by James Tobin. James Tobin in Lindenberg and Ross (1981), stated that Tobin's q is an indicator for measuring company performance, especially about the firm value that shows a management proforma in managing the company's assets. If the value of Tobin's $q>1$, then the stock price is in 
overvalued condition which means that management has been successful in managing the company's assets. Conversely, if the price of shares in undervalued condition, it means that management has failed in managing the company's assets.

\section{Dividend Policy}

Brigham and Houston (2006) argue that the optimum dividend policy of a company must achieve a balance between current dividends and future growth so as to maximize stock prices. Three theories about investor preferences regarding dividend policy are:

\section{1) Dividend Irrelevance Theory}

Some argue that the dividend policy has effect neither on the stock price of the company nor on its cost of capital. If the dividend policy has no significant effect, then it is irrelevant. The supporters of the irrelevance of the dividend policy are Modigliani-Miller (MM).

\section{2) Thory of Bird in the Hand}

This theory was proposed by Myron Gordon (1959) and John Lintner (1956) who argued that equity will decrease if the dividend payout ratio is raised, as investors are less confident of capital gains generated from retained earnings than if investors receive dividends. Gordon and Lintner argued that investors are much more appreciative of the expected earnings from dividends than those from capital gains. Bird in the hand theory states that the firm value will be maximized by setting a high dividend payout ratio.

\section{3) Tax Preference Theory}

Tax Preference or Tax Differential theory was proposed by Litzenberger and Ramaswamy, stating that due to taxes on dividends and capital gains, investors prefer capital gains because they can delay tax payments (Atmaja, 2008). The theory of tax preference stipulates three tax-related reasons for assuming that investors would prefer lower dividend payments to high dividend payouts, namely: (1) long-term capital gains will be taxed less than dividend income, (2) taxes of the profits will not be paid until the shares are sold, because of the effect of time value, and (3) when a piece of stock owned by someone until he dies, there is absolutely no profit tax payable (Brigham and Houston, 2006).

\section{Debt Policy}

Debt policies include corporate financing policies that are sourced from external parties. Determination of debt policy is related to capital structure since debt is one of composition in capital structure.

\section{1) Trade Off Theory}

In 1958 Modigliani and Miller (MM) showed an evidence that the firm value was not affected by the capital structure, the evidence was based on a set of assumptions, among others, no brokerage fees, no taxes, no bankruptcy fees, investors can borrow at the same rate as the company's rate, all investors have common information, EBIT is not affected by the cost of debt.

\section{2) Signaling Theory}

Brigham and Houston (2001) argued that signaling is an action taken by the management of a company that provides guidance for investors about how management views the prospects of the company. Companies with lucrative prospects will try to avoid the sale of shares and seek new capital in other ways such as by using debt.

\section{Independent Commisioners}

The practice of corporate governance requires the existence of an independent commissioners within the company that are expected to create an independent, objective 
and equitable climate as the main principle in respecting the interests of minority shareholders and other stakeholders.

\section{Institutional Ownership}

Institutional Ownership is the proportion of share ownership by institutional investors. Institutional Investors are believed to have a better ability to A research conducted by Ludwina, Ratna (2012) on Comprehensive Analysis of the Influence of Family Ownership, Agency Problems, Dividend Policy, Debt Policy, Corporate Governance and Opportunity Growth on Firm Value using multiple linier regression analytical method showed that Debt Policy has no effect on firm value, Dividend policy has an effect on firm value, opportunity growth is not proven to significantly influence negatively the relationship between dividend policy and firm value.

Kamal Ghalandari (2013) in The Moderating Effects of Growth Opportunities on the Relationship between Capital Structure and Dividend Policy and Ownership Structure with Firm Value in Iran: Case Study of Tehran Securities Exchange using multiple linier regression analytical method showed that Capital Structure dan Dividend Policy is significantly influencing the firm value. The moderating variabel of Growth Opportunities influences the relationship between the Firm Value and Capital monitor management actions than individual investors have. Institutions as shareholders are considered more capable in detecting errors. While Rubin (2005) argued that institutional shareholders, with large shareholdings, have an incentive to monitor corporate decision making.

\section{Previous Researches}

Structure, Dividend Policy, dan Ownership Structure

Malihe Rostami (2015) addressing The Effect of Ownership Structure on Tobin's q Ratio using multiple linier regression analytical method showed that Legal Shareholders, Individual Shareholder, Largest Shareholders, Large Shareholder are negatively significant on Tobin's q Ratio.

Teguh, Prayogo (2015) in The Moderating Effect of Growth Opportunities on the Relationship Between Financing Decision, Dividend Policy, Profitability and Liquidity Toward Firm Value using multiple linier regression analytical method showed that Financing Decision, Profitability have positive and significant influence, while Dividend Policy, Liquidity have positive but insignificant influence. Variable of Growth Opportunities has significant influence on the relationship of Firm Value and Financing Decision, Profitability and Liquidity, and Growth Opportunities have insignificant influence on the relationship of Dividend Policy and Firm Value. 


\section{Theoritical Framework}

Figure 1

Theoritical Framework

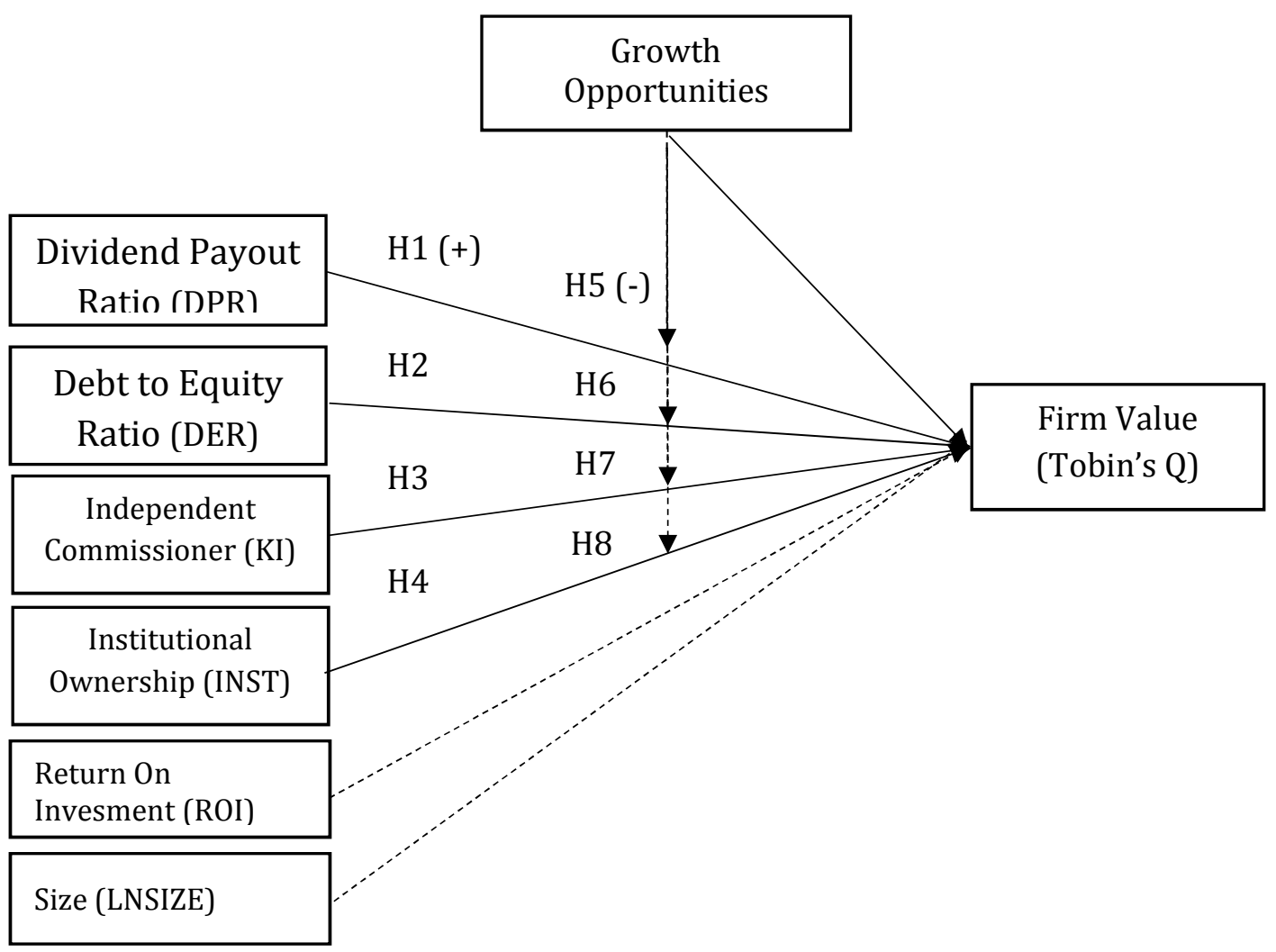

Source: data processed by the authors, 2017

\section{RESEARCH METHODOLOGY}

\section{Types and Sources of Data}

The type of data used in this study was secondary data, including the company's annual financial statements and stock trading activities report which includes Debt to Equity Ratio (DER), Dividend Payout Ratio (DPR), Independent Commissioner (KI), Institutional Ownership (INST), Firm Value (Tobin's q), Growth Opportunities (MBV), company size and ROI.

\section{Population and Sample}

The population of this study is nonfinancial companies listed on the Indonesia Stock Exchange in 2012 until 2015. Sample selection was done using purposive sampling method. The data of financial statements and annual reports used were from the perionds of 2012 to 2015.

\section{Data Collection Method}

Data collection was done by documentation method by collecting sample financial reports on the Indonesia Stock Exchange's website (www.idx.co.id), Indonesian Capital Market Directory (ICMD) from 2012 to 2015, domestic and overseas journals, and other supporting references.

\section{Operational Definition of Variables}


The operational definition of the variables to be used in this study can be described as follows:

\section{1) Dependent variable}

Dependent variable is an influenced variable or a variable which becomes the result of the existence of independent variable (Sugiyono, 2009: 39). The dependent variable in this study is firm value measured using Tobin's q.

2) Independent variable

Independent variabile is an influencing variable or variable being the cause of the change or the incidence of dependent variable (Sugiyono, 2009: 59). Independent variables in this research were Debt to Equity Ratio (DER), Dividend Payout Ratio (DPR),
Independent Commissioner (KI), and Institutional Ownership (INST).

3) Moderator variable

The moderator variable is the variable that affects (strengthens and weakens) the relationship between the dependent variable and the independent one. This study used indicators for growth opportunity variables (Market Opportunity) in the form of Market to Book Value (MBV) showing the value of a company obtained by comparing the market value of the company (market value - MV) to its book value - BV.

4) Control variable

In testing the hypotheses in this study, some research models will be developed by including some control variables, namely: firm size and Return on Investment (ROI).

Table 1

Operational Definition of Variables

\begin{tabular}{|c|c|c|c|c|}
\hline No & Variable & $\begin{array}{c}\text { Operational } \\
\text { Definition }\end{array}$ & Measurement & Scale \\
\hline 1 & $\begin{array}{l}\text { Firm Value } \\
\text { (Tobin's q) }\end{array}$ & $\begin{array}{l}\text { The ratio of the stock } \\
\text { price to the book } \\
\text { value per share. }\end{array}$ & $\begin{array}{c}\text { (Stock Price } x \text { Number of Stocks) }+ \text { Debt } \\
\text { Total Asset }\end{array}$ & Ratio \\
\hline 2 & $\begin{array}{l}\text { Debt to Equity } \\
\text { Ratio (DER) }\end{array}$ & $\begin{array}{l}\text { Comparison of total } \\
\text { debt to own capital. }\end{array}$ & $\begin{array}{l}\text { Total Debt } \\
\text { Total Equity }\end{array}$ & Ratio \\
\hline 3 & $\begin{array}{l}\text { Dividend Pay out } \\
\text { Ratio (DPR) }\end{array}$ & $\begin{array}{l}\text { Dividend per share } \\
\text { divided by earnings } \\
\text { per share. }\end{array}$ & $\begin{array}{c}\text { Dividend per Share Sheet } \\
\text { Earnings per Share }\end{array}$ & Ratio \\
\hline 4 & $\begin{array}{l}\text { Independent } \\
\text { Commissioner } \\
\text { (KI) }\end{array}$ & $\begin{array}{l}\text { Members of the board } \\
\text { of commissioners who } \\
\text { are not affiliated with } \\
\text { the management, } \\
\text { other members of the } \\
\text { board of } \\
\text { commissioners, and } \\
\text { controlling } \\
\text { shareholders, are free } \\
\text { from business } \\
\text { relations or other }\end{array}$ & $\frac{\text { Number of independent commissioners }}{\text { Number of boards of commissioners }}$ & \\
\hline
\end{tabular}




\begin{tabular}{|c|c|c|c|c|}
\hline No & Variable & $\begin{array}{l}\text { Operational } \\
\text { Definition }\end{array}$ & Measurement & Scale \\
\hline & & $\begin{array}{l}\text { relationships that may } \\
\text { affect their ability to } \\
\text { act independently. }\end{array}$ & & \\
\hline 5 & $\begin{array}{l}\text { Institusional } \\
\text { Ownership } \\
\text { (INST) }\end{array}$ & $\begin{array}{l}\text { Ownership of shares } \\
\text { by Institutional parties } \\
\text { within the company. }\end{array}$ & $\begin{array}{c}\text { Number of shares owned by Institutional } \\
\text { Total shares outstanding }\end{array}$ & \\
\hline 6 & $\begin{array}{l}\text { Growth } \\
\text { Opportunities } \\
(M B V)\end{array}$ & $\begin{array}{l}\text { The ratio of stock } \\
\text { price to book value } \\
\text { per share per year. }\end{array}$ & $\begin{array}{l}\text { Share Price per Sheet } \\
\text { Book Value per Share }\end{array}$ & Ratio \\
\hline 7 & $\begin{array}{l}\text { Return } \quad \text { On } \\
\text { Invesment (ROI) }\end{array}$ & $\begin{array}{l}\text { Capital capability } \\
\text { invested in overall } \\
\text { assets to generate } \\
\text { profits. }\end{array}$ & $\frac{\text { Net Profit After Tax }}{\text { Total Asset }}$ & Ratio \\
\hline 8 & $\begin{array}{l}\text { Company } \quad \text { Size } \\
\text { (LnSize) }\end{array}$ & $\begin{array}{l}\text { The amount of assets } \\
\text { owned by the } \\
\text { company. }\end{array}$ & The value of the logarithm of total assets & \\
\hline
\end{tabular}

\section{Classical Assumption Testing}

The occurrence of deviations of classical assumption in research in the use of multiple regression models in testing the hypothesis is very likely to occur thus should be avoided. In this study the classical assumption that is considered important is that there is no multicollinearity between independent variables, no heteroscedasticity or variant of constant confounding variables (homoscedasticity) and no autocorrelation between residuals of each independent variable (Ghozali, 2001).

\section{Data Analytical Techniques}

The main relationships to be tested in this study are the influences of dividend policy, debt policy, managerial ownership, and institutional ownership on the firm value. The authors added growth opportunities as moderator variables to see the effect of these variables on the relationship between dividend policy, debt policy, managerial ownership, and institutional ownership on firm value. This research models are:

\section{Model 1:}

Tobin's $q=\alpha+\beta 1$ DPR $+\beta 2$ DER $+\beta 3$ KI $+\beta 4$ INTS $+\beta 5$ ROI $+\beta 6$ LNSIZE $+\varepsilon$

Model 2:

Tobin's $q=\alpha+\beta 1 \mathrm{DPR}+\beta 2 \mathrm{DER}+\beta 3 \mathrm{KI}+\beta 4 \mathrm{INTS}+\beta 5 \mathrm{MBV}+\beta 6(\mathrm{DPR} * \mathrm{MBV})+$ $\beta 7\left(\mathrm{DER}^{*} \mathrm{MBV}\right)+\beta 8\left(\mathrm{KI}^{*} \mathrm{MBV}\right)+\beta 9(\mathrm{INTS} * \mathrm{MBV})+\beta 10 \mathrm{ROI}+\beta 11 \mathrm{LNSIZE}+\varepsilon$

Where:

Tobin's q : value of firm i in year $\mathrm{t}$

DPR : Dividend Policy of firm i in year $t$ 


$\begin{array}{ll}\text { DER } & : \text { Debt Policy of firm } \mathrm{i} \text { in year } \mathrm{t} \\ \text { KI } & : \text { Independent Commissioner of firm } \mathrm{i} \text { in year } \mathrm{t} \\ \text { INST } & : \text { Istitutional Ownership of firm } \mathrm{i} \text { in year } \mathrm{t} \\ \mathrm{MBV} & : \text { Growth Opportunities of firm } \mathrm{i} \text { in year } \mathrm{t} \\ \mathrm{DPR} \mathrm{MBV}^{*} & : \text { Variable of interaction of DPR and MBV } \\ \text { DER*MBV } & : \text { Variable of interaction of DER and MBV } \\ \text { KI*MBV }^{*} \text { :Variable of interaction of KI and MBV } \\ \text { INST*MBV }^{*} \text { : Variable of interaction of INST and MBV } \\ \text { LNSIZE } & : \text { Size of firm i in year } \mathrm{t} \\ \text { ROI } & : \text { Return On Investment of firm i in year } \mathrm{t}\end{array}$

Regression Analysis with Moderator Variables

The moderator variable is an independent variable that strengthens or weakens the relationship between independent variables and the dependent ones. Moderated Regression Analysis (MRA) or interaction test is a special application of linear multiple regression where the regression equation contains an interaction element (multiplication of two or more independent variables). In this interaction test, multicolinearity problems are very susceptible to occure because they are caused by the interaction itself that multiplies the independent variables to the moderator variables. There is an alternative to avoid a close relationship due to the interaction that occurs in the model by testing the value of the absolute difference. Frocut and Shearon (1991) in Ghozali (2011) proposed a somewhat different regression model to examine the effect of the moderation using the model of absolute difference values.

\section{F-test (Goodness of Fit)}

This test is used to find out whether the modeling built meets the fit criteria or not. The F-count value can be found by the formula of $(1-\mathrm{R}) /(\mathrm{N}-\mathrm{k}) \mathrm{R} /(\mathrm{k}-1) \mathrm{F}-\mathrm{i} 22$ count. If F-count $>$ F-table $(\mathrm{a}, \mathrm{k}-1, \mathrm{n}-\mathrm{l})$, then $\mathrm{H} 0$ is rejected; and If F-count $<\mathrm{F}$-table $(\mathrm{a}, \mathrm{k}-\mathrm{l}, \mathrm{n}$ - $\mathrm{k})$, then $\mathrm{HO}$ is accepted. At the regression output, the F-test can also be seen by comparing probability values to the predetermined $\alpha$, thus if the comparison results show that the probability value $(0.000)<\alpha(0.05)$ it can be argued that the built model meets the fit criteria.

\section{T-statistical test (Partial)}

The significance test of coefficient (bi) is done by t-statistic. The t-count value can be searched by the formula of i i Standard Error $b$ Regression coefficient (b): calculate $t$ If $t-$ count $>\mathrm{t}$-table $(\alpha, \mathrm{n}-\mathrm{k}-\mathrm{l})$, then $\mathrm{H} 0$ is rejected; and If $\mathrm{t}$-count $<\mathrm{t}$-table $(\alpha, \mathrm{n}-\mathrm{k}-\mathrm{l})$, then $\mathrm{H} 0$ is accepted. At regression output, partial test can also be done by looking at probability value, if probability value $(0.000)<\alpha(0.05)$ hence hypothesis is accepted.

\section{Coefficient of Determination (R2)}

Coefficient of determination (R2) is intended to know how far the ability of the model in explaining the variation of dependent variables (Ghozali, 2011). The value of coefficient of determination (R2) is between 0 (zero) and 1 (one). The value of R2 approaching one means that the independent variables provide almost all the information needed to predict the variation of the dependent variables. 
IV. FINDINGS AND DISCUSSION

\section{Descriptive Statistics}

Based on the financial ratio inputted from the financial statements of banking companies published by each company in the periods of 2011-2015, it can be known the minimum, maximum, mean (average) and standard deviation of each research variable that can be seen in table 2 as follows.

Table 2

Calculation of Minimum, Maximum, Mean, and Standard Deviation Values

\begin{tabular}{|l|r|r|r|r|r|}
\hline & \multicolumn{1}{|c|}{ Descriptive Statistics } \\
\hline TOBIN'S Q & \multicolumn{1}{|c|}{ Minimum } & Maximum & \multicolumn{1}{c|}{ Mean } & Std. Deviation \\
\hline DPR & 112 & 18.54 & 92.35 & 49.7587 & 16.57323 \\
DER & 112 & -60.47 & 1350.54 & 59.8898 & 150.92612 \\
KI & 112 & .18 & 3.40 & 1.0519 & .75505 \\
INST & 112 & 20.00 & 100.00 & 39.4938 & 13.06975 \\
ROI & 112 & 19.96 & 98.18 & 66.5838 & 16.77784 \\
LNSIZE & 112 & -.29 & 91.17 & 13.6804 & 12.07853 \\
MBV & 112 & 12.52 & 19.32 & 16.1632 & 1.60086 \\
Valid N (listwise) & 112 & .14 & 756.27 & 83.8726 & 115.20601 \\
& 112 & & & & \\
\hline
\end{tabular}

\section{First Equation}

The First Model of Determinant Coefficient Test $\left(\mathbf{R}^{2}\right)$

The value of determination coefficient shows the percentage of dependent variables which can be explained by independent variables. The coefficient of determination can be known from the adjusted value of $\mathrm{R}^{2}$. The value of coefficient of determination (adjusted $\mathrm{R}^{2}$ ) of 0.945 means that $94.50 \%$ of Tobin's q variation can be explained by variables of DPR, DER, KI, INST, ROI, and SIZE while the remaining $5.50 \%$ are explained by other causes outside the model regression.

\section{The First Model of F-test (Influence Test Simultaneously)}

The calculation results can be seen that the $F$ value is 316,273 and the significance value is 0,000 so that the F-count $(316,273)>$
F table (1.96) and the value of significance is smaller than $5 \%$ or 0.05 is 0.000 , then it can be concluded that the proposed model has been decent (goodness of fit).

\section{The First Model of Test-t (Partial effect test)}

The influence of independent variables on dependent variables can be seen from beta value of unstandardized coefficient, whereas to know which independent variable that most influences Tobin's q ratio, beta value of standardized coefficient is used. Standard error indicates a data error that can cause the result to be biased due to the large outliers. Standard error is also used as the denominator variable in t-count. The standard error value below 1 means that the outliers are relatively low, while if the standard error value above 1 , it means that 
the outliers is relatively high. The linear regression equation that can be compiled on the test results is as follows:
Tobin's q $=10,324-0,001 \mathrm{DPR}+46,440$ $\mathrm{DER}+0,66 \mathrm{KI}-0,107$ INST + 0,122 ROI - 0,154 LNSIZE

\section{Second Equation}

Second Model of Determinant Coefficient Test ( $\left.\mathbf{R}^{2}\right)$

The value of determination coefficient shows the percentage of dependent variables which can be explained by independent variables. The coefficient of determination can be known from the adjusted value of $\mathrm{R}^{2}$. The value of coefficient of determination (adjusted $\mathrm{R}^{2}$ ) of 0.920 means that $92.0 \%$ of Tobin's q variation can be explained by variables of DPR, DER, KI, INST, ROI, and SIZE with MBV as moderator variables, while the remaining $8 \%$ are explained by other causes beyond the regression model.

\section{The Second Model of F-test (Influence Test simultaneously)}

The results of SPSS calculation can be seen that the value of $\mathrm{F}$ is 115.304 and the significance value is 0.000 so that F-count (115.304)> F-table (1.96) and the significance value is less than $5 \%$ or 0.05 that is 0.000 hence it can be concluded that the proposed model is worthy (goodness of fit).

\section{The Second Model of t-test (Partial influence test)}

The influence of independent variables on the dependent variables can be seen from the beta value of unstandardized coefficient, while to know which independent variable that most affect the profitability, the beta value of standardized coefficient is used. Standard error indicates a data error that can cause the result to be biased due to the large outliers. Standard error is also used as the denominator variable in t-count. The standard error value, if it is below 1, means that the outliers are relatively low. Contrarily, if the standard error value is above 1 , it means that the outliers are relatively high. The linear regression equation that can be compiled on the test results is as follows:

$$
\begin{aligned}
\text { Tobin's q }= & 51,593+1,518 \mathrm{DPR}+15,841 \\
& \mathrm{DER}+1,465 \mathrm{KI}-1,910 \mathrm{INTS}+ \\
& 3,236 \mathrm{MBV}-2,174|\mathrm{DPR}-\mathrm{MBV}| \\
& -0,404|\mathrm{DER}-\mathrm{MBV}|-1,801 \mid \mathrm{KI}- \\
& \mathrm{MBV}+1,573|\mathrm{INTS}-\mathrm{MBV}|+ \\
& 0,584 \mathrm{ROI}-0,270 \mathrm{LNSIZE}+\varepsilon
\end{aligned}
$$

The result of t-test regression for model 1 and model 2 of DPR variable on model 1 and model 2 shows the insignificant influence on firm value on the level of $5 \%$. DER, KI, INST variables in models 1 and 2 have a significant effect on firm value. While control variable of ROI in model 1 has significant effect and it in model 2 has not significant effect, while the control variable of LNSIZE in models 1 and 2 has no significant effect on the level of $5 \%$ level. Moderator variables of $\mathrm{MBV}, \mathrm{DPR} * \mathrm{MBV}, \mathrm{KI} * \mathrm{MBV}$ and INST * MBV in model 2 show significant influences, whereas DER * MBV in model 2 have no significant effect on the level of $5 \%$ on the firm value 
Table 3

Summary of t-Test Regression Results of Model 1 and Model 2

\begin{tabular}{lrrrrrr}
\hline & \multicolumn{3}{c}{ Model 1 } & \multicolumn{3}{c}{ Model 2 } \\
\cline { 2 - 7 } Variables & t-statistics & Sig. & $\begin{array}{c}\text { Significant / } \\
\text { Not Significant }\end{array}$ & t-statistics & Sig. & $\begin{array}{c}\text { Significant / } \\
\text { Not Significant }\end{array}$ \\
\hline DPR & -.531 & .597 & Not Significant* & 1.811 & .073 & Not Significant* \\
\hline DER & 42.785 & .000 & Significant* & 28.184 & .000 & Significant* \\
\hline KI & 2.272 & .025 & Significant* & 2.637 & .010 & Significant* \\
\hline INST & -4.166 & .000 & Significant* & -3.550 & .001 & Significant* \\
\hline ROI & 3.673 & .000 & Significant* & 1.083 & .282 & Not Significant* \\
\hline LNSIZE & -.610 & .543 & Not Significant* & -.507 & .613 & Not Significant* \\
\hline MBV & & & & 3.539 & .001 & Significant* \\
\hline DPR*MBV & & & & -2.353 & .021 & Significant* \\
\hline DER*MBV & & & & -.499 & .619 & Not Significant* \\
\hline KI*MBV & & & & -2.278 & .025 & Significant* \\
\hline INST*MBV & & & & 2.139 & .035 & Significant* \\
\hline *At Significant & & & & &
\end{tabular}

${ }^{*}$ At Significant Level of 5\%

4. Discussion

The Influence of Dividend Policy on Firm Value

In the first equation model, the regression coefficient of dividend payout ratio (DPR) is equal to -.531 with a significance value of 0.597 greater than 0.05 indicates that DPR has no effect on the firm value (Tobin's q) of non-financial companies in the IDX in the periods of 2012-2015, so the first hypothesis is rejected. While the second equation model which inserts MBV as moderator variable shows a regression coefficient equal to 1.811 with a significance value of 0.073 greater than 0,05 indicates that DPR does not influence on the firm value (Tobin's q).

From the analysis results, it is concluded that dividend policy has no effect on firm value. These results can be seen from 28 samples observed over four years. The results show that the dividends distributed by the sample companies for four years of research are relatively similar, such as the dividends distributed by PT Astra International Tbk which distributes 45\% dividends for 2012, 2013 and 2014. This indicates that the amount of dividends that the company distributes to shareholders is not related to the firm value. These results are in line with the Dividend Irrelevance Theory (Irrelevant Dividend) presented by Modigliani-Miller (MM) arguing that the dividend policy has no effect on the stock price of the company nor on the cost of its capital. If the dividend policy has no significant effect, then it is irrelevant. Based on the company's investment decision, dividend payout does not affect the shareholder's welfare. Company value is determined by the ability of the company to generate profits and enlarge the company's assets with investment decisions or policies it arranges.

The Influence of Debt Policy on Firm Value In the first equation model, the regression coefficient of debt policy variable 
proxied with debt to equity ratio (DER) of 42.785 with a significance value of 0.000 less than 0.05 indicates that DER is positively affecting the firm value (Tobin's q) of nonfinancial firms listed in IDX in the periods of 2012-2015, so that the second hypothesis is accepted. Whereas the second equation model that incorporates MBV as a moderator variable shows a regression coefficient of 28.184 with a significance value of 0.000 greater than 0.05 indicates that DPR influences the firm value (Tobin's q).

Test conducted on the variable of debt policy proxied by DER shows that debt policy has a positive and significant impact on firm value. The results of this study are in accordance with Trade-off theory explaining that if the position of capital structure is below the optimal point then any additional debt will increase the value of the company. And vice versa, if the position of capital structure is above the optimal point then any additional debt will lower the value of the company. Therefore, assuming that optimal target of capital structure has not been reached, hence, based on trade-off theory, it can be predicted that there is a positive relation to the firm value. Solihah and Taswan (2002) in their research indicated that debt policy has a positive but insignificant effect on firm value. The results of this study are consistent with Modigliani and Miller's findings in 1963 that by incorporating corporate income taxes, the use of debt will increase the value of the firm. Hasnawati (2005) and Teguh, Prayogo (2015) in their research indicated that funding decisions have a positive effect on firm value.

\section{The Influence of Independent Commissioner on Firm Value}

The research results about the influence of independent commissioner on firm value show that the significance value is 0.025 where the significance is smaller than 0.05 so that the third hypothesis is accepted. So it can be concluded that the independent commissioner has a significant effect on the firm value. The results of research show that $t$ value equal to 2.272 and it can be seen that the research coefficient has positive value which means that by more independent commissioners the company value will increase. Hary Wisnu (2014) stated that the independent commissioner has a positive influence on the firm value. He said that the more the independent commissioners, the more the firm value. The independent status focuses on the responsibility of protecting shareholders, especially independent shareholders from fraudulent practices or committing capital market crimes. The interest of shareholders protected by independent commissioners will reduce the occurrence of frequent fraud committed by the management of the company so that shareholders feel secure and will increase the firm value.

\section{The Influence of Institutional Ownership on Firm Value}

The results of this research about the influence of independent commissioner to firm value shows a significance value of 0,000 where the significance is smaller than 0.05 so that the third hypothesis is accepted. So it can be concluded that the independent commissioner has a significant effect on the value of the company. The result of research shows that $t$ value is equal to $-4,166$ and it can be seen that the research coefficient is negative which means that more institutional ownership will decrease the firm value.

Institutional ownership is the proportion of share ownership by institutional investors. Institutional investors in their supervision are relatively weak, so 
they are not able to make the company to increase its value. Institutions as shareholders are considered more capable in detecting errors that occur. However, Institutional investors are temporary owners, so they are only focusing on current earnings. If changes in current earnings are not felt favorable by investors, investors can liquidate their shares. Institutional investors usually have large shares, so if they liquidate their shares it will affect the value of the stock as a whole. To avoid liquidation actions from investors, managers will take earnings management actions that can reduce the firm value.

\section{The Influence of Dividend Policy on Firm Value with Growth Opportunities as Moderator Variables}

The results of this research about the influence of dividend policy on the firm value with growth opportunities as moderator variable show the significance value of 0.021 which is smaller than 0.05 , so that the fifth hypothesis is accepted. The results of the research show that $t$ value is equal to -2.353 and it can be seen that the research coefficiency is negative. So it can be concluded that growth opportunities as moderator variable weaken the relationship between dividend policy and firm value. Companies that grow doing investment in assets more than firms that those do not grow. The growth of the company requires high capital, so the profit generated by the company is more used to make investments rather than distributed to shareholders through dividends. These results support Kusuma's (2006) study to prove that growing companies provide smaller dividends from non-growing companies do. Because, the retained earnings generated by some companies are allocated for their business expansion.
The Influence of Debt Policy on Firm Value with Growth Opportunities as Moderator Variables

The results of this research about the effect of debt policy on firm value with growth opportunities as moderating variable show a significance value of 0.573 which is greater than 0.05 so that the third hypothesis is rejected. The results show that $t$ value is 0.404 and it can be seen the research coefficiency is negative. So it can be concluded that growth opportunities as moderating variables do not affect the relationship between debt policy and firm value. Growth opportunities can weaken the relationship between debt policy and firm value but insignificant, so that the sixth hypothesis is rejected.

Growing opportunities play a role in influencing company policy, such as debt policy, dividend policy, and others. Companies that experience growth rates will need additional capital to finance their growth. Company management will take decisions that can support the creation of a good growth rate for itself. However, debt policy can increase the risk of the company, especially for investors, so that it can lower the stock price and lower the firm value.

The Influence of Independent Commissioner on Firm Value with Growth Opportunities as Moderator Variables

The results of research about the influence of Independent Commissioner on the firm value with growth opportunities as moderating variables show a significance value of 0.025 which is smaller than 0.05 so that the seventh hypothesis is accepted. The results of research show that $t$ value is equal to -2.278 and it can be seen that the research coefficiency is negative. So it can be concluded that growth opportunities as 
$\begin{array}{lll}\text { moderating } & \text { variables } & \text { weaken the } \\ \text { relationship } & \text { between } & \text { independent }\end{array}$ commissioners and firm value, so the hypothesis of eight is rejected.

Growth Opportunities weaken the relationship of independent commissioners with firm value, meaning that the greater the chance of growth the more the independent commissioners that impact on the declining value of the company. The existence of the independent commissioner within the company observed in this study is only a formality to comply with the provisions or regulations stipulated by the Indonesia Stock Exchange so the independent commissioner can not perform its function as supervisor who monitors the policies of directors and management of the company. The function of independent commissioners is to take control in directing the company to run it operations in accordance with predetermined standards so that the company will have better growth opportunities and achieve its goals. However, if an independent commissioner owned by the company does not perform its function as supervisor and monitoring division then it can not reduce the value of the company. The more chances of firm growth the more the independent commissioners leading to the decline of the firm value.

The Influence of Institutional Ownership on Firm Value with Growth Opportunities as Moderator Variables

The results of research on the effect of Institutional Ownership on firm value with growth opportunities as moderating variables show a significance value of 0.035 which is smaller than 0.05 , so that the eighth hypothesis is accepted. The results show that $t$ value of 2.139 and it can be seen that the coefficiency of the research is positive. So it can be concluded that growth opportunities as moderating variables strengthen the relationship between dividend policy and firm value.

High supervision within the company can prevent the occurrence of irregularities or limit the policies taken by management that can reduce the value of the company. A high degree of institutional ownership will result in greater oversight efforts by Institutional investors so as to impede opportunistic manager behavior. Barnae and Rubin (2005) argued that institutional shareholders, with large shareholdings, have INSTentive to monitor corporate decision making. Chung and Charoenwong (1991) stated that the essence of corporate growth is the existence of profitable investment opportunities. If there is a lucrative investment opportunity, the manager tries to take advantage of opportunities to maximize shareholder wealth.

\section{CONCLUSION AND IMPLICATIONS OF THE POLICY}

1. Conclusion

Based on the results of data analysis and discussion that have been put forward, some conclusions can be drawn as follows: the data used in this study have normal distribution; there is no multicollinearity, no autocorrelation and no heteroscedasticity. Of the 8 proposed hypotheses, there are four accepted hypotheses and four rejected ones.

1) Hypothesis 1 in equation model 1 shows partially that variable of Deviden Payout Ratio (DPR) has negative relation and not significant to variable of Company Value (Tobin's q) so that hypothesis 1 is rejected. While the second equation model shows that variable of Deviden Payout Ratio (DPR) partially has a positive and insignificant relationship to the variable of Tobin's q

2) Hypothesis 2 on both the equation 1 and 2 shows partially that Debt to Equity 
Ratio (DER) variable has positive and significant effect on Tobin's q variable. Hence the second hypothesis is received.

3) Hypothesis 3 shows partially that the Independent Commissioner's variable has a positive and a significant influence on the Firm Value (Tobin's q) so that the third hypothesis is accepted.

4) Hypothesis 4 shows partially Institutional Ownership (INST) variable has negative and significant influence on the Firm Value (Tobin's q) then the fourth hypothesis is rejected.

5) Hypothesis 5 shows partially that variable of Deviden Payout Ratio (DPR) has negative and significant influence on the Firm Value (Tobin's q) with moderating variables of Growth Opportunities (MBV) then the fifth hypothesis is accepted.

6) Hypothesis 6 shows that partially Debt to Equity Ratio (DER) variable has negative and insignificant effect on Tobin's Value (q) with moderating Growth Opportunities (MBV), so that the sixth hypothesis is rejected.

7) Hypothesis 7 shows partially Independent Commissioner variable has a negative and a significant effect on the variable on the firm value (Tobin's q) with Growth Opportunities (MBV) as moderating variable then the seventh hypothesis is rejected.

8) Hypothesis 8 shows partially that variable of Institutional Ownership (INST) has a positive and significant effect on Tobin's Value (q) with moderating Growth Opportunities (MBV), so that the eighth hypothesis is accepted.

\section{Implications of The Policy}

The policy implications suggested in this study to increase the Firm Value are as follows:

1) Managerial implications for investors are that variables of debt policy and dividend policy can be used as one indicator in investment decision making. Dividend policy is a signal that the company is able to generate profits. The company's debt policy affects the value of the firm, where the size of the firm's debt affects the company's ability to generate profits. High debt levels can lower the firm value, but to increase the asset, the company must make investments that require large funds so that companies need to make debt policy.

2) Managerial implementations for the company are that the company needs to establish the policy of the composition of independent commissioners within it. This is in accordance with the practice of corporate governance requiring the existence of independent commissioner within the company which is expected to create an independent, objective and equitable climate as the main principle in observing the interests of minority shareholders and other stakeholders. 


\section{REFERENCES}

Asmawati (2013). Pengaruh Struktur Kepemilikan, Keputusan Keuangan Terhadap Nilai Perusahaan: Profitabilitas sebagai Variabel Moderating. Jurnal Ilmu \& Riset Akuntansi, Vol.2 No.4.

Bathala CT., Moon KP., Rao RP. (1994). Managerial Ownership, Debt Policy and THE Impact of Institusional Holding: An Agency Perspective. Financial Management Vol.23 No.3, $38-50$.

Carningsih (2009), Pengaruh Good Corporate Governance Terhadap Hubungan Antara Kinerja Keuangan Dengan Nilai Perusahaan, Universitas Gunadarma.

Dwi Sukirni (2012). Kepemilikan Manajerial, Kepemilikan Institusional, Kebijakan Deviden dan Kebijakan Hutang Analisis Terhadap Nilai Perusahaan. Accounting Analysis Journal, Vol.1 No.2, ISSN 2252-6765.

Euis Soliha \& Taswan (2002). Pengaruh Kebijakan Hutang Terhadap Nilai Perusahaan serta Beberapa Faktor yang Mempengaruhinya. Jurnal Bisnis dan Ekonomi.

Ghozali, Imam. (2005). Aplikasi Analisis Multivariate Dengan Program. Edisi ketujuh. Badan Penerbit Universitas Diponegoro. Semarang.

Hansen, D. R. \& Mowen, M. M. Alih bahasa oleh Hermawan, A. A. (2007). Akuntansi manajemen, jilid 1. Jakarta: Penerbit Erlangga.

Hary Wisnu P, Subowo (2014). Pengaruh Good Corporate Governance Terhadap Nilai Perusahaan dengan Corporate Social Responsibility sebagai Variabel Intervening. Accounting Analysis Journal, Vol.3 No.3, ISSN 2252-6765.

Hyun-Han Shin, Rene M. Stulz (2000). Firm Value, Risk and Growth Opportunities. National Bureau of Economic Research.

Iturriaga, F. J.L., dan Sanz J. A. R. 1998. Ownership Structure, Corporate Value and Firm Investment: a Spanish Firms Simulataneous Equations Analysis. Working Paper Universidad de Valladolid, pp. 1-32.

Kamal Ghalandari (2013). The Moderating Effects of Growth Opportunities on the Relationship between Capital Structure and Dividend Policy and Ownership Structure with Firm Value in Iran: Case Study of Tehran Securities Exchange. Research Journal of Applied Sciences, Engineering and Technology 5(4), 1424 - 1431.

Lindenberg, E.B, and Ross, 1981. Tobin's q Ratio and Industrial Organization. Journal of Business, 54 (1), 1-32.

Malihe Rostami (2015). The Effect of Ownership Structure on Tobin's q Ratio. Journal of Research in Business, Economics and Management (JRBEM), ISSN: 2395-2210. 
Modigliani, Franco and Merton H. Miller (1958). The Cost of Capital, Corporation Finance and Theory of Invesment. American Economic Review, 48:3, 261 - 297.

Nigel Driffield, Vidya M, Sarmistha P. (2007). How Does Ownership Structure Affect Capital Structure and Firm Value? Recent Evidence from East Asia. Centre for Economic Development \& INSTitutions Discussion Paper Series No. 07-04.

Teguh Prayogo A, Ardianto (2015). The Moderating Effect of Growth Opportunities on the Relationship between Financing Decision, Dividend Policy, Profitability and Liquidity Toward Firm Value. Simposium Nasional Akuntansi 18.

Sujoko dan Soebiantoro, Ugy (2007). Pengaruh Struktur Kepemilikan Saham, Leverage, Faktor Intern dan Faktor Ekstern terhadap Nilai Perusahaan (Studi Empirik pada Perusahaan Manufaktur dan Non Manufaktur di Bursa Efek Jakarta), Jurnal Manajemen dan Kewirausahaan, Vol 9, 41-48

Varun Dawar (2014). Agency Thoery, Capital Structure and Firm Performance: Some Indian Evidence. Journal Managerial Finance, Vol.40 No.12 , 1190 - 1206.

Wardoyo, Theodora M.V. (2013). Pengaruh Good Corporate Governance , Corporate Social Responsibility dan Kinerja Keuangan Terhadap Nilai Perusahaan. Jurnal Dinamika Manajemen, Vol.4 No.2, 132 - 149. 